\title{
New Data about Crusts of Weathering on Kimberlites of Diamondiferous Territories
}

Zintchouk, N.N.

YaGEER\&D CNIGRI, ALROSA Co. Ltd. Chernyshevsky Sh. 7, Mirny, 678170, Sakha (Yakutia), Russia.

On ancient platforms, where kimberlite magmatism is established, both large and relatively small in size kimberlite pipes are revealed, with the developed residual crust of weathering on most of them. The analysis of geologic-mineralogical features and composition of crusts of weathering on kimberlite pipes of Yakutian diamondiferous province, which was carried out by us, has shown that intensively chemically refined kimberlites (with a very limited number of cases) are earmarked only in some regions of this territory. The pipe named after the 23d Congress of the CPSU is an example of such deeply chemichally refined crust of weathering of Yakutian kimberlites. In the section of this pipe one can trace clearly expressed zonal ștructure of eluvial products. Lower zone (with the thickness of 5-7 m) represents loose multicolored kimberlite rock with clearly expressed fragmentary structure. Upper zone (with the thickness of 7-8 $\mathrm{m}$ ) is composed by brown (seldom by light-grey) clayey formations, which practically have not preserved structure-textural features of mother rocks. In the products of weathering of the pipe in question, together with montmorillonite and disordered montmorillonitehydromicaceous mixed-layer formations there is present in a considerable quantity hydromica of polytypic modification IM, chlorite (from packets 6 and $6^{i}$, according to Zvyagin B.B.), as well as serpentine (structural types A+B). Picroilmenite prevails in the complex of heavy fraction initial minerals. The number of pyropes reduces upward along the profile of weathering. The share of other rather stable minerals of heavy fraction (chromite, chrome-diopside, zircon, rutile, sphene and others) in general is insignificant. Goethite, hematite and siderite prevail in authigenic complex of heavy fraction minerals. Sufficiently different type of the kimberlite crust of weathering was revealed by us on a number of other small kimberlite pipes of Yakutia (Dachnaya, International, et al., for instance). It turned out to be often impossible to make a clear distinction between compact and weathered kimberlites in such pipes, either in field conditions (during registration of performed mining works), or by the results of laboratory processing of stone material. By the degree and character of kimberlite rocks' alteration this distinction, with some share of relativity, can be made only by distribution in the section of clayey minerals. In such profiles, independent of the position of rocks in the section, one can reveal kimberlites of different stages of weathering. Hardly altered rocks, practically completely preserving structure-textural features of initial kimberlites, belong to the first stage. The second stage includes moderately weathered rocks, in which relict structures of kimberlite and various nodules being present in them preserve as a rule, but to various degree are shaded by secondary ferruginous-clayey formations. Greatly weathered rocks, initial structure-textural features of kimberlites in which practically are not preserved, belong to the third stage. Very often the rocks of this stage of weathering are represented 
by slightly uneven saturated with hydro-oxides of iron and clayey formations. Their colour, due to irregular distribution of ferruginous compounds, changes from greyishyellow, yellowish-grey to brown colour of various shades. $\mathrm{Mg}$ - $\mathrm{Fe}$ montmorillonite associating with variable amount of disordered montmorillonite-hydromicaceous mixed layer phase dominates in the products of weathering. Sites of weathering crust are earmarked therewith, enriched by close to Ca-form variety of montmorillonite, though in general there prevails the mineral with mixed composition of cations in interlayer intervals of its structure. Kaolinite, hydromica, chlorite, serpentine and in individual samples palygorskite are present in subordinated quantity in pelitic component of the products of weathering.

Nearly equal contribution of the first and the second factor to the total variability of the system (the sum of the first four-factors is over 90\%) is characteristic feature of the investigated type of kimberlite crust of weathering, under general comparatively high organization of petrochemical system. This equality testifies that two close in intensity processes, changing the initial appearance of kimberlite rocks of the pipe, are taking place in the crust of weathering of this type. In accord with the revealed in the rocks groups of components $\left(\mathrm{Al}_{2} \mathrm{O}_{3}-\mathrm{Fe}_{2} \mathrm{O}_{3}-\mathrm{FeO}-\mathrm{MnO}-\mathrm{K}_{2} \mathrm{O}-\mathrm{P}_{2} \mathrm{O}_{5}, \mathrm{CaO}-\mathrm{Na}_{2} \mathrm{O}, \mathrm{TiO}_{2}-\mathrm{K}_{2} \mathrm{O}\right)$ the first factor monitors the behaviour of $\mathrm{Al}, \mathrm{Fe}^{3+}, \mathrm{Fe}^{2+}, \mathrm{Mn}, \mathrm{K}$ and $\mathrm{P}$ (fixation in rocks) as well as of $\mathrm{Ca}$ (release). On the other hand, the second factor determines accumulation of $\mathrm{CaO}$ and $\mathrm{CO}_{2}$ in individual sites, which is mainly connected with carbonatization of individual sites of the section. This factor allows to assess the scales of release of $\mathrm{SiO}_{2}$, $\mathrm{Al}_{2} \mathrm{O}_{3}$ from the rock, partial redistribution and oxidation of $\mathrm{Fe}$ with formation of $\mathrm{Fe}_{2} \mathrm{O}_{3}$ in the last case. The third factor monitors the behaviour of $\mathrm{TiO}_{2}$, partially of oxide iron and $\mathrm{Na}_{2} \mathrm{O}$ (fixation). In general, rather monotonous distribution of main accessory elements is characteristic of this type of weathering profiles, which stresses small chemical transformation of kimberlites of such pipes. The following paragenetic associations of elements have been earmarked: Be - V - Ga - P, Mn - Co - B, C - Ni, F - C.

Despite the difference in the structure of individual kimberlite pipes, related in the first turn with different types of rock and their physical-mechanical properties, the processes of alteration of initial minerals in their sections and cropping up of secondary minerals are common, the nature of secondary varieties being directly related with structural and crystallochemical features of initial minerals. By character of transformation the latter are subdivided into two groups: minerals of insular, chain and framework structure, as well as of layer one. Minerals of the first group in the process of hypergene transformation dissolve from the cropping up products as well, depending on $\mathrm{pH}$ and Eh environment new minerals are crystallized. At the same time micas and other hypogenic layer silicates undergo degradational transformation with the rise of either similar polytypic modifications of the same type varieties of initial minerals, or new individual layer minerals and broad gamma of mixed layer formations.

Structural and crystallochemical features of initial minerals stipulate their different stability during weathering and they can be arranged in the order of reduction of their stability in the row: quartz, potassium field -spars, amphiboles, pyroxenes, acid plagioclases, basic plagioclases, olivine, volcanic glass, carbonates and salts. Accordingly 
layer silicates form their own succession: muscovite and dioctahedral hydromicas $2 \mathrm{M}_{\mathrm{l}}$, glauconites, celadonites and other hydromicas IM, dioctahedral varieties of montmorillonite-hydromicaceous mixed layer formations and montmorillonite, ditrioctahedral varieties of mixed layer formations and chlorite, trioctahedral montmorillonites and chlorites, chlorite-montmorillonites and chlorite-vermiculites, trioctahedral varieties of micas and hydromicas, as well as serpentines.

Investigated kimberlites contain minerals with rather various structure, in particular a small part of serpentine, mica (mainly phlogopite), field spars, hornblende, some part of carbonates, and various oxides and hydroxides of elements of the iron (ferrum) group, as well. That is why in accordance with their physical-chemical properties they transform into new hypergene minerals in some definite succession. Thus, serpentines for instance, for the varieties of which in a number of investigated by us kimberlites the mixture of polytypic modifications $A+B$ is established. At early stages of weathering under retention of initial $\mathrm{pH}$ and $\mathrm{Eh}$, but reduction of pressure and especially environmental temperature, the lowest temperature modification A from the polytypes in question preserve. With the reduction of both $\mathrm{pH}$ and Eh environment thereafter intensive decomposition of serpentine takes place, and from the products of its destruction at first there crop up $\mathrm{Mg}-\mathrm{Fe}^{2+}$ - montmorillonite (that is, mineral of trioctahedral type), later $\mathrm{Mg} \mathrm{Fe}^{3+}-$ montmorillonite of intermediate di-trioctahedral type, and then - $\mathrm{Fe}^{3+}-\mathrm{Al}$ variety of this mineral, corresponding to proper dioctahedral type. It its turn, phlogopite in restorational situation is transformed into chlorite from $\mathrm{Fe}^{2+}-\mathrm{Mg}$ to practically $\mathrm{Mg}$-type, and in oxidation situation - into vermiculite and subsequent transformational products of the latter. At first association of $\mathrm{Mg}-\mathrm{Fe}^{3+}$ - montmorillonite and vermiculite develops by way of vermiculite. Further on the structure of the association undergoes "homogenization" with the formation of disordered vermiculite-montmorillonite mixed layer phase. Subsequent complete dioctahedronization of vermiculite packets and their transformation into montmorillonite ones leads to cropping up of relatively uniform dioctahedral montmorillonite. Small quantity of hydromica IM crops up from phlogopite as well. Biotite also undergoes congenial alterations. Owing to chemical composition (availability of $\mathrm{Al}$ and $\mathrm{Fe}^{3+}$ in octahedrons) and more favourable combination of individual elements of the structure (polytypic modification $2 \mathrm{M}_{1}$ ) dioctahedral micas (muscovite, et al.) are more stable than their trioctahedral analogs. In the result of it they preserve in the profiles of weathering down to the lower parts of upper zone. At the early stages of hypergenesis plagioclases, as well as serpentine and hornblende, are dissolved and dioctahedral montmorillonite is synthesized from the products of their destruction, structural features of which are determined by acidity of basic initial plagioclases. The products of complete dissolution or partial transformation of a number of accessory minerals also contribute to formation of hypergene minerals, especially oxides and hydroxides of iron (ferrum) group. And here the degree of ordered structure of initial minerals is inherited by newly rising phases.

Thus, if in the zonal crust of weathering of individual pipes' kimberlites one can clearly trace in the section the replacement of initial rocks by eluvium with corresponding to each zone mineral associations, then in the majority of investigated small in size 
kimberlite bodies, owing to loose composition of rocks, macrouniform eluvial thickness is formed. However microseparations in the sections of the latter type are characterized by zonal structure with close to greatly altered pipes succession of initial rocks' transformation. It follows herefrom that the ordered structure of initial minerals, their inheritance by newly formed hypergene phases and universal nature of the processes, taking place therewith, independently of the type of weathering rocks and specific features of their aggregate state, are the main factors which determine regularity of successive transformation of various rocks in the process of weathering.

Application of these provisions when investigating eluvial thick layers opens opportunity not only to objectively assess structural and crystallochemical nature of cropping up secondary products and their genetic relationship with initial minerals in each zone, but to forecast character orientation of rocks' alteration under the effect of hypergene processes with taking into account temperature and hydrochemical regimes of weathering. 